Engineer Research and

Development Center

Engineering for Polar Operations, Logistics, and Research (EPOLAR)

\title{
Structure and Stability of the McMurdo Ice Shelf Transition Zone and Glaciated Hillside near Scott Base, Antarctica
}

Seth Campbell, Nathan Lamie, and Kristin Schild

April 2018

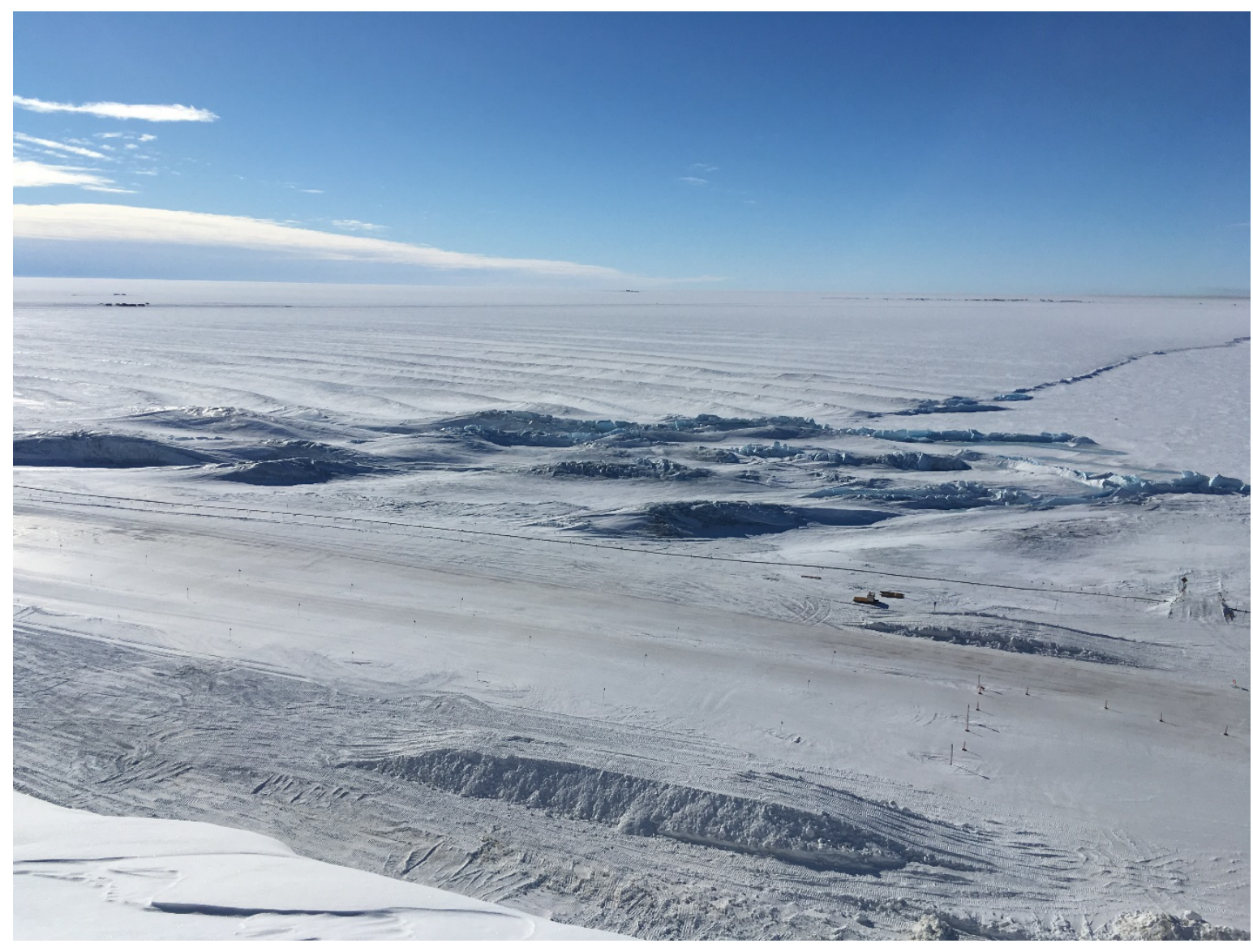


The U.S. Army Engineer Research and Development Center (ERDC) solves the nation's toughest engineering and environmental challenges. ERDC develops innovative solutions in civil and military engineering, geospatial sciences, water resources, and environmental sciences for the Army, the Department of Defense, civilian agencies, and our nation's public good. Find out more at www.erdc.usace.army.mil.

To search for other technical reports published by ERDC, visit the ERDC online library at http://acwc.sdp.sirsi.net/client/default. 


\section{Structure and Stability of the McMurdo Ice Shelf Transition Zone and Glaciated Hillside near Scott Base, Antarctica}

Seth Campbell and Nathan Lamie

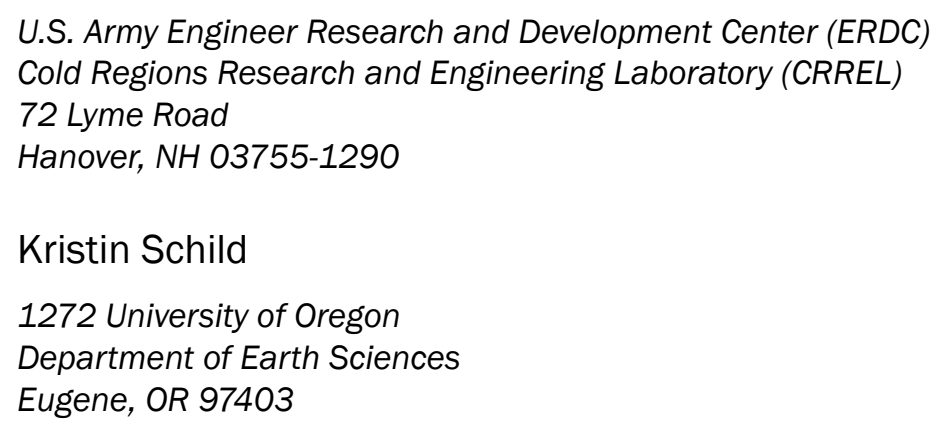

Final Report

Approved for public release; distribution is unlimited.

Prepared for National Science Foundation, Office of Polar Programs 2415 Eisenhower Avenue Alexandria, VA 22314

Under Engineering for Polar Operations, Logistics, and Research (EPOLAR) EP-ANT-16-32, "Reconnaissance of a New Potential Road Site to Replace the Transition Zone Road." 


\section{Abstract}

We used ground-penetrating radar and Global Positioning System surveys in November 2015 and January 2016 to determine ice depth and ice flow velocities of a glacier-covered hillside neighboring the Transition Zone (TZ) on McMurdo Ice Shelf (MIS), Antarctica. We also analyzed two available high-resolution digital elevation maps to establish how surface elevations are changing across the region. These surveys were conducted to determine if the TZ Road, the primary U.S. Antarctic Program access to ice-shelf operations, can be relocated onto the hillside if it becomes unpassable in the future. The results suggest that construction and maintenance of a road on the TZ hillside would be challenging due to (1) steep slopes, (2) minimal snow and firn cover available for maintenance activities, (3) significant annual changes to the surface, and (4) substantial ice thicknesses and ice flow velocities that will alter any constructed road on an annual basis. Despite these primary findings, the observed change in ice cover both on the hillside and within the transition zone itself suggest that efforts to develop a new road should continue to help ensure longterm access and use of ice-shelf-based facilities for McMurdo and Scott Stations.

DISCLAIMER: The contents of this report are not to be used for advertising, publication, or promotional purposes. Citation of trade names does not constitute an official endorsement or approval of the use of such commercial products. All product names and trademarks cited are the property of their respective owners. The findings of this report are not to be construed as an official Department of the Army position unless so designated by other authorized documents. 


\section{Contents}

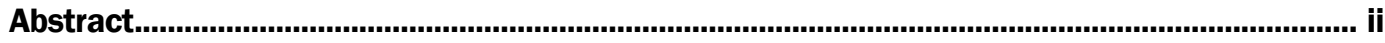

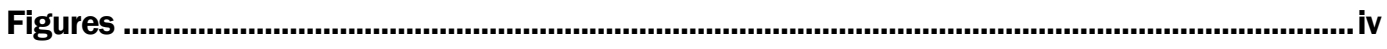

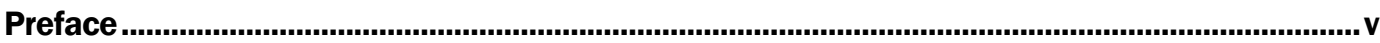

Acronyms and Abbreviations .................................................................................................. vi

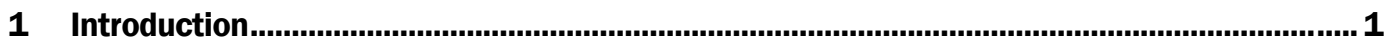

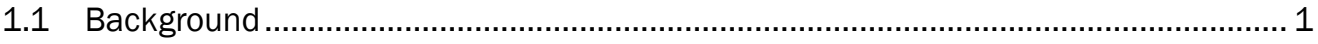

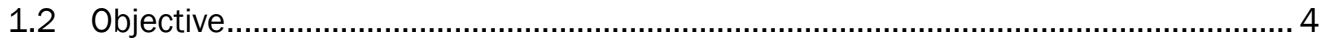

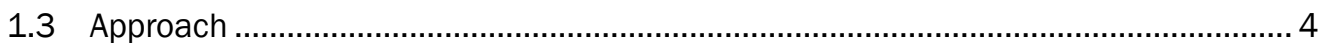

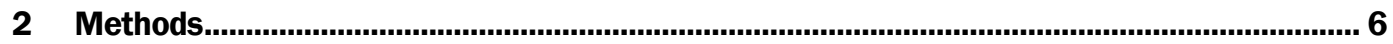

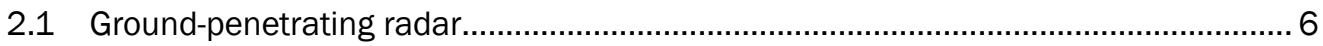

2.2 Global Positioning System ................................................................................. 7

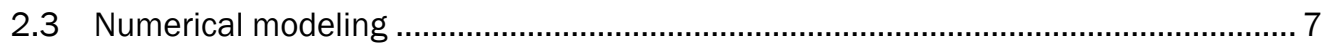

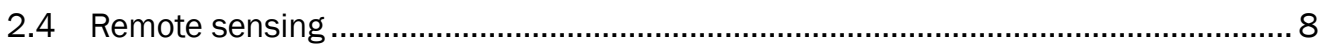

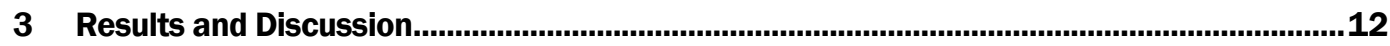

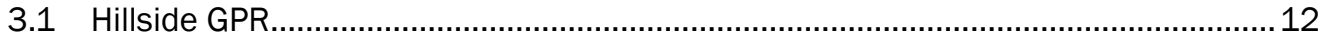

3.2 Transition Zone GPR ...................................................................................... 13

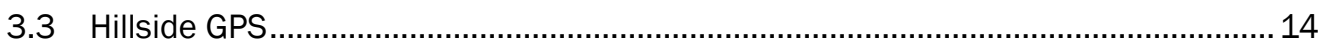

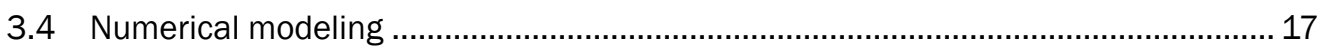

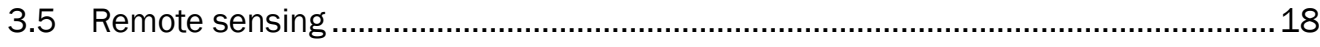

4 Conclusions and Recommendations …...........................................................................22

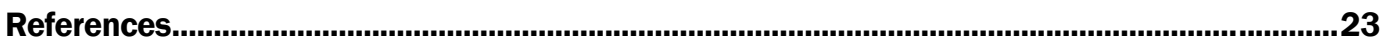

\section{Report Documentation Page}




\section{Figures}

1 RADARSAT Imagery (1997) showing ice diverging from Ross Ice Shelf (RIS) into McMurdo Ice Shelf (MIS) and ice flow from Ross Island into MIS.

2 Aerial View of the Transition Zone (TZ), Scott Base, TZ Road onto the ice shelf, and the neighboring hillside on Hut Point Peninsula, which is the primary focus of this study

3 Worldview satellite image (left) and zoom (right) acquired in September of 2016 showing a new fracture that is approximately $150-200 \mathrm{~m}$ wide and $500 \mathrm{~m}$ long (arrows) along the ice shelf-sea ice transition within the TZ. This fracture was not evident in similar imagery acquired between March 2015 and March 2016

4 Digital elevation models (DEMs) from a 2014 LiDAR dataset, a 2011 Worldview (WV) dataset, and a $2015 \mathrm{WV}$ dataset.

5 Histogram showing the number of pixels (frequency) on the y-axis for each pixel value on the $x$-axis. Pixel value ( $x$-axis) represents the difference between the 2015 WV image and the 2014 LiDAR image over the bedrock AOI (Fig. 4, blackoutlined polygon), which we assume remains constant in elevation.

6 Histogram showing the number of pixels (frequency) on the $y$-axis for each pixel value on the $x$-axis. Pixel value (x-axis) represents the difference between the 2011 WV image and the 2014 LiDAR image over the bedrock AOI, which we assume remains constant in elevation

7 A $400 \mathrm{MHz}$ GPR profile showing rough bed topography and ice thicknesses to 50 $\mathrm{m}$. Some stratification is still visible within the top $20 \mathrm{~m}$ of ice.

8 A $400 \mathrm{MHz}$ GPR profile (a) and $100 \mathrm{MHz}$ GPR profile (b) showing bed topography and a likely buried cinder cone (arrow) under the TZ Hillslope

9 A $400 \mathrm{MHz}$ GPR profile collected along the centerline of the TZ Road in January of 2015 showing near surface, conformable stratigraghy (SCS), complex syncline $(\mathrm{S} F)$, and anticline folds $(A F)$ of the meteoric ice and discontinuous stratified marine ice below.

10 A map of the 2016 GPR transects with color of the transects indicating measured ice thicknesses on the hillside beside the TZ and arrows indicating ice-flow velocities measured by GPS stakes (green circles) during November 2016-January 2017.

11 Snapshot of the three-dimensional finite element numerical model of the TZ hillside showing modeled ice flow velocities $\left(\mathrm{m} \mathrm{a}^{-1}\right)$ and a slice of the proposed road.

12 The elevation changes between the normalized WV 2011 and normalized WV 2015 DEM scenes. A majority of the region experienced a decrease in elevation, up to $\sim 3.3 \mathrm{~m}$, between 2011 and 2015

13 A map of surface slope derived from the WV 2015 DEM. Surface slopes on the hillside range from $5^{\circ}$ to $28^{\circ}$ with increasing slopes near the bergschrund, which is located immediately above the TZ road. Slopes on the ice shelf are small $\left(1^{\circ}-4^{\circ}\right)$.

14 Modeled solar insolation, which includes only direct and total diffuse insolation calculated for 2015 based on the 2015 WV DEM. Note the lower values in the TZ relative to the TZ hillslope. Reflected insolation is not included within this model. 


\section{Preface}

This study was conducted for the National Science Foundation, Office of Polar Programs (NSF-OPP) under Engineering for Polar Operations, Logistics, and Research (EPOLAR) EP-ANT-16-32, "Reconnaissance of a New Potential Road Site to replace the Transition Zone Road." The technical monitor was Ms. Margaret Knuth, NSF-OPP, Antarctic Infrastructure and Logistics.

The work was performed by the Engineering Resources Branch (CEERDRZE) of the Research and Engineering Division (CEERD-RR), U.S. Army Engineer Research and Development Center, Cold Regions Research and Engineering Laboratory (ERDC-CRREL), and the University of Oregon. At the time of publication, Mr. Jared Oren was Chief, CEERD-RZE; Mr. J. D. Horne was Chief, CEERD-RR; and Ms. Janet Hardy was the program manager for EPOLAR. The Deputy Director of ERDC-CRREL was Dr. Lance D. Hansen, and the Director was Dr. Joseph L. Corriveau.

We appreciate the Polar Geospatial Center for providing GIS (geographic information system) mapping support and UNAVCO (University NAVSTAR Consortium) for providing GPS (Global Positioning System) support. We also appreciate the Antarctic Support Contractor for providing key logistical support, specifically U.S. Antarctic Program's Ms. Meghan Walker, Ms. Bija Sass, Ms. Meghan Parks, Ms. Beverley Walker, and Mr. John Loomis. We also appreciate the assistance of Dr. John Fegyveresi, Mr. Chris Simmons, Mr. Jim Mediatore, Mr. Evan Miller, Dr. John Stone, Mr. Perry Spector, and Mr. Trevor Hillebrand who helped to conduct the fieldwork.

COL Bryan S. Green was Commander of ERDC, and Dr. David W. Pittman was the Director. 


\section{Acronyms and Abbreviations}

\begin{tabular}{|c|c|}
\hline $\mathrm{AOI}$ & Area of Interest \\
\hline CRREL & Cold Regions Research and Engineering Laboratory \\
\hline DEM & Digital Elevation Model \\
\hline EPOLAR & Engineering for Polar Operations and Logistics \\
\hline ERDC & Engineer Research and Development Center \\
\hline FIR & Finite Impulse Response \\
\hline GIS & Geographic Information System \\
\hline GPR & Ground-Penetrating Radar \\
\hline GPS & Global Positioning System \\
\hline GSSI & Geophysical Survey System Incorporated \\
\hline LiDAR & Light Detection and Ranging \\
\hline MIS & McMurdo Ice Shelf \\
\hline NSF & National Science Foundation \\
\hline OPP & Office of Polar Programs \\
\hline TWTT & Two-Way Travel Time \\
\hline $\mathrm{TZ}$ & Transition Zone \\
\hline UNAVCO & University NAVSTAR Consortium \\
\hline USAP & U.S. Antarctic Program \\
\hline WV & WorldView \\
\hline
\end{tabular}




\section{Introduction}

\subsection{Background}

Hut Point Peninsula is the logistical hub for both the U.S. and New Zealand Antarctic programs; and therefore, melting and other changes to McMurdo Ice Shelf (MIS) have been a great concern for almost 60 years (e.g., Paige 1968). Recent findings of West Antarctic Ice Sheet and shelf instabilities (Rignot et al. 2014; Joughin et al. 2014) suggest that MIS should be closely monitored and that a heightened level of concern should exist for logistical infrastructure established on or at its margins. Several potential "single-point failures" would jeopardize the entirety of U.S. Antarctic Program (USAP) operations; one such failure would be the interruption of MIS Runway operations. The primary vehicle entrance or exit from MIS onto Hut Point, where Scott Base and McMurdo Station are situated, is via the Transition Zone (TZ) (Figure 1). The TZ is a triaxial point of stress where the MIS buttresses against Hut Point Peninsula of Ross Island at the ice shelf-sea ice transition. The buttressing of ice leads to compression folds, severe fracturing, and complex ice dynamics (Figure 2). Meltwater runoff from the nearby hillside of Hut Point has caused severe ponding on the TZ. Although the ponding is partially alleviated by drain holes into the relatively porous and fractured ice shelf, the subsurface influence of meltwater on the ice, proximity of the TZ to the ice shelf-sea ice edge, and complex dynamics are concerning for long-term stability.

During the winter of 2016, a new ice-shelf fracture approximately $200 \mathrm{~m}$ wide and $500 \mathrm{~m}$ long formed parallel to and upstream of the ice-shelf edge at the TZ (Figure 3). A relatively stable and long-term rift near Pegasus Runway also lengthened by approximately $4 \mathrm{~km}$, resulting in the separation of a 14-17 km² iceberg from the MIS terminus (Banwell et al. 2017). Nearly coincident in timing, an approximately $4 \mathrm{~km}$ long and $1.5 \mathrm{~m}$ wide fracture situated upstream of Pegasus and Phoenix runways also lengthened by at least $3 \mathrm{~km}$. This fracture has been monitored using high-precision GPS (Global Positioning System) instrumentation and stakes installed on either side. Results suggest that the fracture has separated $78 \mathrm{~cm}$ over the past year, reaching a total fracture width of $2.56 \mathrm{~m}$ wide as of 11 November 2017. This extension and widening now pose logistical difficulties 
because the fracture crosses the Black Island Traverse Route, which is used yearly by the USAP.*

Figure 1. RADARSAT Imagery (1997) showing ice diverging from Ross Ice Shelf (RIS) into McMurdo Ice Shelf (MIS) and ice flow from Ross Island into MIS. Ice flow from RIS (1) and Ross Island (2) is approximately demarcated by the white dotted line. The white dashed line distinguishes the MIS terminus. Approximate ice flow directions are represented by white dotted arrows. Other labeled items include White Island $(W)$ Black Island $(B)$, the Black Island Traverse route $(B / T)$, Pegasus Runway $(P)$, Phoenix Runway $(P H)$, Williams Field Skiway $(W$, and the Transition Zone (TZ). The inset map shows the location of McMurdo Station (MCM) and Scott Base, located only $2.5 \mathrm{~km}$ from McM, in Antarctica. Both bases reside at the tip of Hut Point (HP) near the MIS terminus. Red dashed lines denote new or extended iceshelf fractures or crevasses discussed in the text.

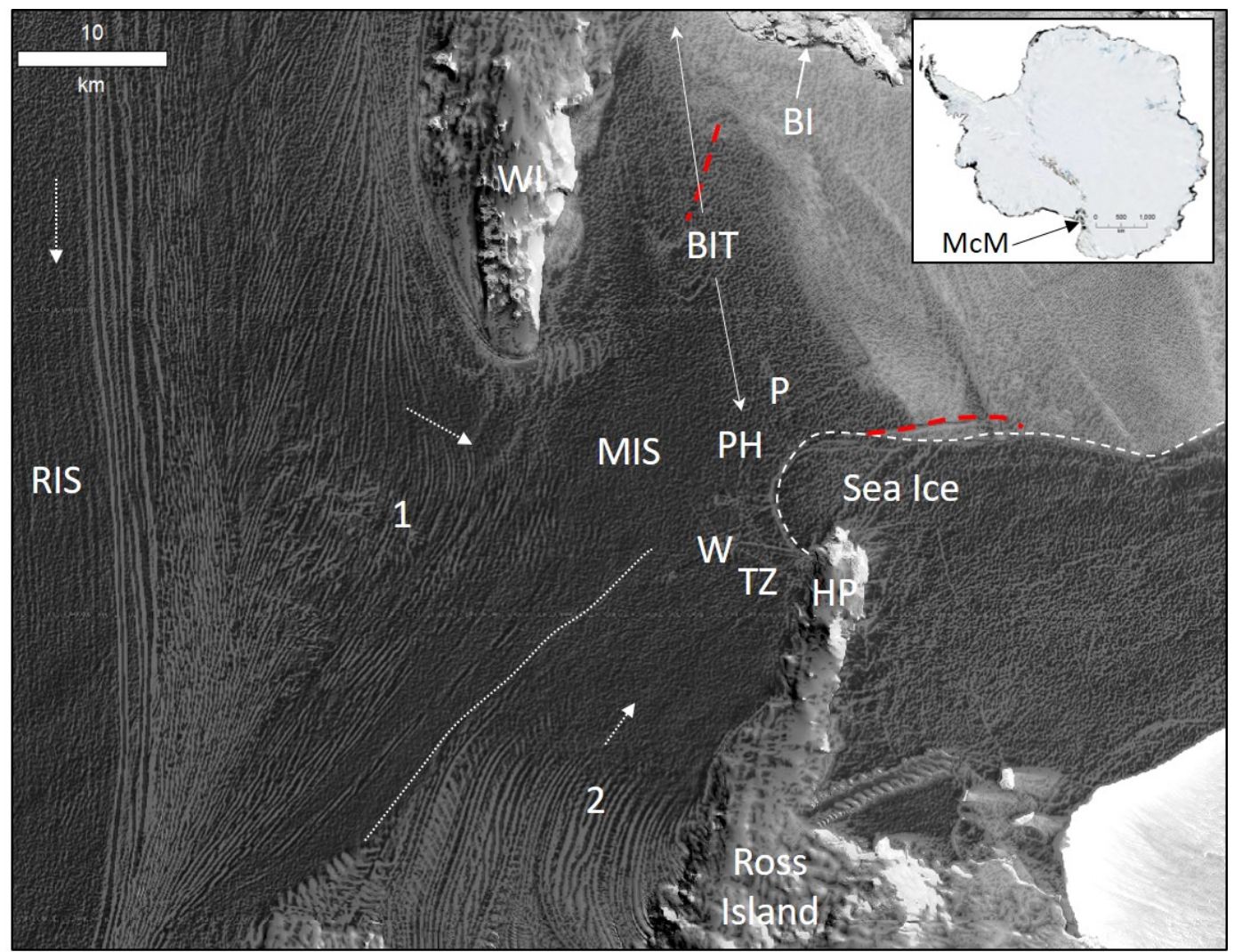

* J. Loomis, personal communication, November 2016. McMurdo Station, Antarctica: U.S. Antarctic Program. 
Figure 2. Aerial View of the Transition Zone (TZ), Scott Base, TZ Road onto the ice shelf, and the neighboring hillside on Hut Point Peninsula, which is the primary focus of this study. Note the compression folds and melt ponds within the TZ and transition from the ice shelf to sea ice (black dotted line). Arrows represent approximate ice flow directions based on compressional fold orientations. (Photo courtesy of Ben Roth, 2015.)

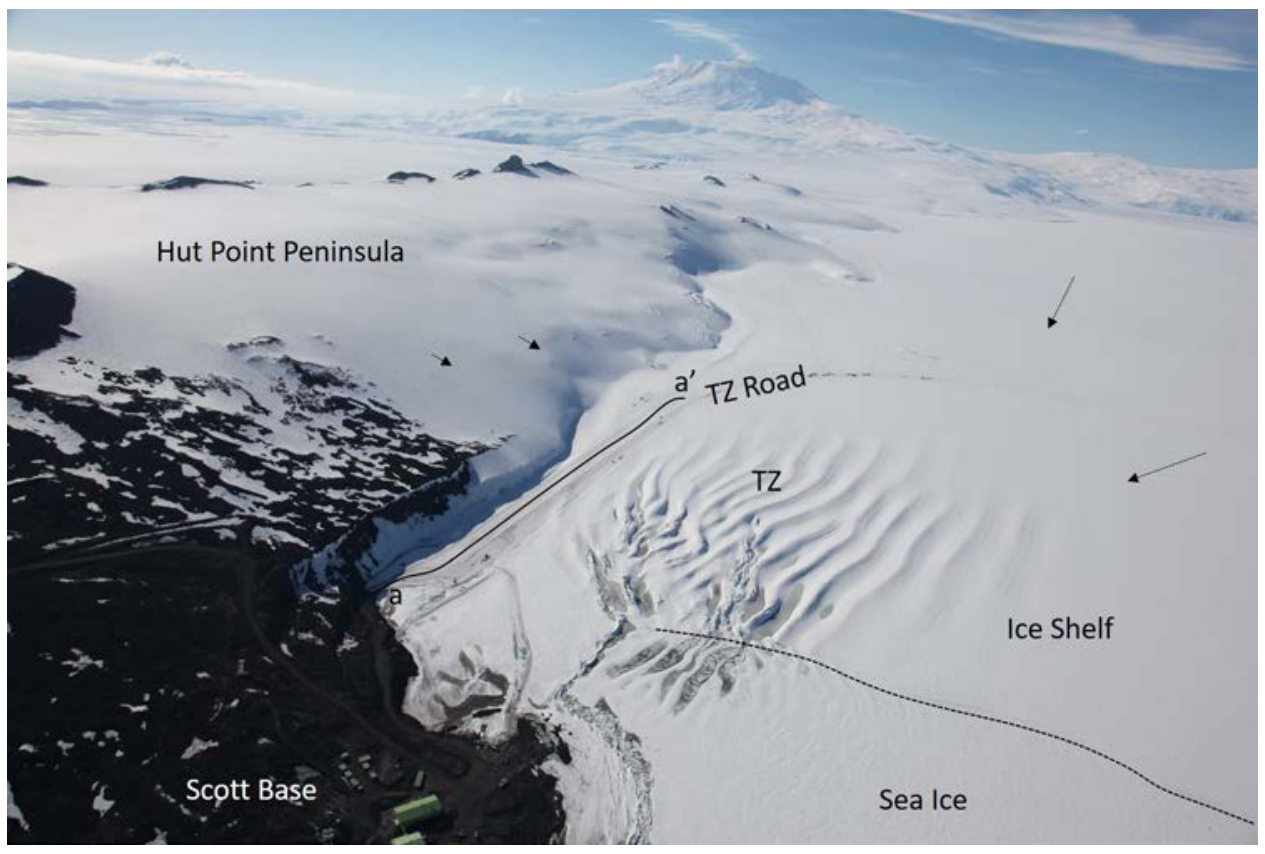

Figure 3. Worldview satellite image (left) and zoom (right) acquired in September of 2016 showing a new fracture that is approximately $150-200 \mathrm{~m}$ wide and $500 \mathrm{~m}$ long

(arrows) along the ice shelf-sea ice transition within the TZ. This fracture was not evident in similar imagery acquired between March 2015 and March 2016.
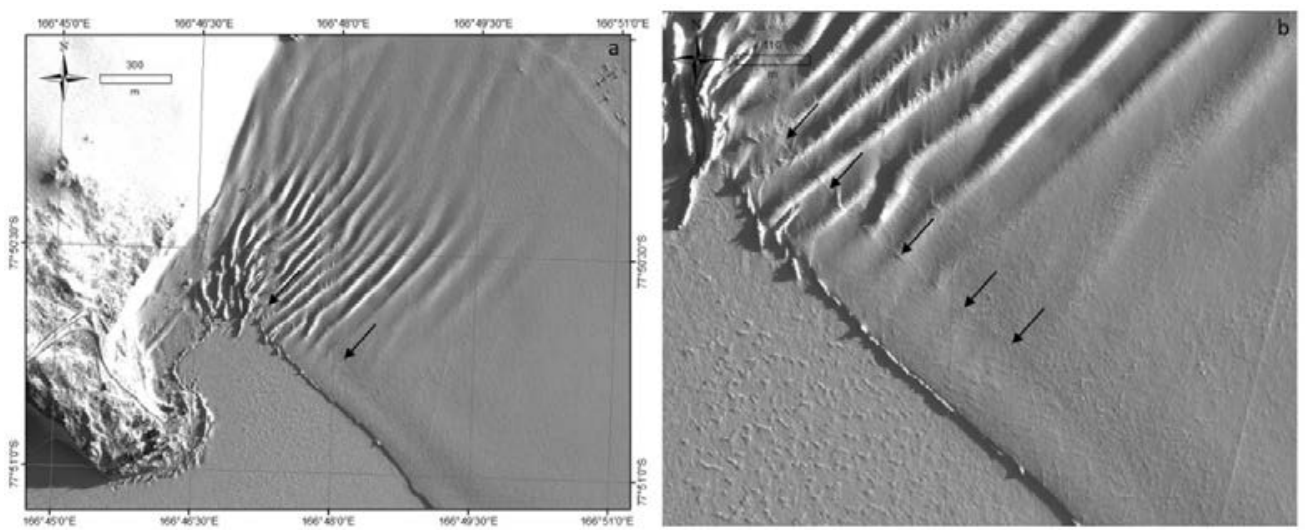

GPS surveys in 2016 revealed changing surface velocities on MIS, likely in response to the decreased ice mass at its terminus (Banwell et al. 2017), supporting previous geodetic studies that suggest that some MIS thinning 
has occurred within the last decade. ${ }^{*}$ These events suggest that some dynamical changes are occurring on MIS at and upstream of its terminus, which could impact the TZ and MIS logistical operations. At a larger scale, MIS, White Island, and Ross Island act as a lateral margin to Ross Ice Shelf. Hence, changes to MIS could propagate up glacier and influence broader ice-shelf dynamics as evidenced at other recent ice-shelf events (e.g., Jansen et al. 2015).

MIS is bound by Ross Island, White Island, and Black Island (Figure 1). Ice that flows into this region originates from Ross Ice Shelf and the glaciated Ross Island (Figure 1). The ice-shelf front currently terminates in front of Scott Base, which is situated on Ross Island's Hut Point in an area called the TZ. Ice flows into MIS at 100-230 m/year, based on prior available data, with slower velocities closer to the $\mathrm{TZ}$ attributed to buttressing against Hut Point. This buttressing results in compression with significant folding and fracturing of ice at the TZ. The hillside that MIS buttresses against at Hut Point is the primary study site for this project; however, we also present some remote-sensing and geophysical results from the TZ.

\subsection{Objective}

Potential for changes to the ice-shelf front, and namely the TZ, has led USAP to search for new access points from Hut Point to MIS and to enlist the U.S. Army Cold Regions Research and Engineering Laboratory (CRREL) to pursue this concern. Therefore, CRREL conducted groundpenetrating radar (GPR) and GPS surveys of ice depth and glacier ice flow velocities, respectively, on the $\mathrm{TZ}$ and hillside neighboring the $\mathrm{TZ}$ to determine if the existing MIS access road from Scott Base could be relocated onto the hillside if the TZ becomes unstable over the long term.

\subsection{Approach}

This work used a systematic GPS and GPR survey of the TZ hillside near the MIS terminus to quantify ice flow velocities, subsurface structure, and ice thicknesses in 2016-2017. This report assesses two possibilities regarding construction of a new road on the TZ hillside. The first possibility is to create a bedrock-based road by removing snow and ice on the hillside. This option would only be feasible from a maintenance perspective if the ice flow velocities are slow and the ice is thin uphill from the proposed

\footnotetext{
* L. Copland, personal communication about remote sensing research on McMurdo Ice Shelf, December 2016. Ottawa, Canada: University of Ottawa.
} 
road. A second alternative would be to create a snow road on the hillside to access MIS. To accomplish this, a region to the south of the TZ would need to be filled with snow to lessen the hill slope. Ice flow velocities also partially dictate the feasibility of this option as does surface slope and the availability of snow and firn as fill material. The GPR survey of the hillside, in conjunction with ice flow velocity measurements and an assessment of available remote-sensing imagery from the region, provides answers to these critical questions and is a necessary step to determine whether the $\mathrm{TZ}$ road can be relocated to the hillside if the current location continues to deteriorate. We also use results from this study to infer the possible influences the hillside dynamics have on TZ structure and dynamics. 


\section{Methods}

\subsection{Ground-penetrating radar}

The GPR profiles were collected in November 2016 on the hillside beside the TZ Road. We used a Geophysical Survey Systems Incorporated (GSSI) SIR-4000 GPR control unit coupled with a GSSI model 3207AP $100 \mathrm{MHz}$ antenna and a GSSI model $50400400 \mathrm{MHz}$ antenna. Scans were recorded for 1000-1400 ns TWTT (two-way travel time) at 24 scans s $^{-1}$ with 2048 samples per scan. The GPR was synced with a Garmin GPSMap78, which recorded GPS locations at a frequency of $1 \mathrm{~Hz}$. Antennas were towed by hand at approximately $0.25 \mathrm{~m} \mathrm{~s}^{-1}$, resulting in traces being recorded approximately every $1 \mathrm{~cm}$ in horizontal distance. Estimated precision of GPR profiles based on the accuracy of GPS data is $2-4 \mathrm{~m}$. We used a relative permittivity ( $\dot{\varepsilon})$ of ice (3.1) for all depth calculations on the hillside as it had minimal snow or firn cover and was primarily ice, suggesting a constant radio wave velocity relative to depth. Associated wave velocities used for depth calibration were therefore $0.169 \mathrm{~m} \mathrm{~ns}^{-1}$ based on equation (1):

$$
V=\frac{c}{\sqrt{\varepsilon}}
$$

where $V$ is velocity in $\mathrm{m} \mathrm{ns}^{-1}$ and $c$ is the speed of light.

Based on the TWTT and wave velocity, we therefore recorded approximately 50-60 samples $\mathrm{m}^{-1}$, which is more than sufficient to maintain a smooth waveform given the frequencies used. High- and low-pass finite impulse response (FIR) filtering between $100-800 \mathrm{MHz}$ and $25-300 \mathrm{MHz}$ for the 400 and $100 \mathrm{MHz}$ antennas, respectively, were applied during data collection. Profiles were postprocessed using GSSI Radan Version 7.0 proprietary software. Post-processing included time zero correction, integration of GPS data into the files, horizontal filtering to remove ringing and the direct wave within the data, and stacking to improve signal-to-noise ratios and visualization of horizontal reflectors. At a GPR scan rate of 24 scans $\mathrm{s}^{-1}$ and a GPS scan rate of $1 \mathrm{~Hz}$, we acquired a GPS measurement to geolocate each radar profile every 24 radar scans. The GPS location of each GPR scan between measured GPS points was automatically calcu- 
lated by Radan. We used the same software to pick bedrock TWTT and associated bedrock depth based on the wave velocity for ice. Interpretation of GPR profiles follow methods outlined by Campbell et al. (2017).

\subsection{Global Positioning System}

Twenty-two $2 \mathrm{~m}$ long bamboo stakes were placed in a grid on the hillside and measured with GPS in November 2016 and January 2017 to estimate ice flow velocities and associated rates of deformation. Stakes were drilled $1 \mathrm{~m}$ into the ice by using a Kovacs auger. The location of each survey stake was measured with a Trimble R7 and Zephyr Geodetic Antenna. We used a base station established in McMurdo Station to correct GPS data. This base station provided a baseline of 2-2.6 km from our survey grid, which is well within the normal range for base-station-corrected GPS surveys. Standard high-precision GPS surveys require baseline distances less than $10 \mathrm{~km}$ to maintain small systematic position uncertainties. Stakes were measured on 12-15 November 2016 and again on 2 January 2017, resulting in 47-51 days between surveys. The difference in location of each survey stake was used to calculate ice flow velocity, and the combined network of stakes was used to understand the overall deformation field.

\subsection{Numerical modeling}

The combination of a surface digital elevation model (DEM) and ice thickness measurements from GPR were used to develop raster datasets, which were merged to constrain top and bottom surfaces of a three-dimensional finite element numerical model in COMSOL Multiphysics (Version 5.2a). Model boundary conditions included a no slip bed, normal surface stress, and open boundaries at the inlet (top of the hill) and outlet (bottom of the hill near the TZ). Ice flow is driven from gravitational forcing. Minimal snow or firn cover allowed for a constant density $(\rho)$ of ice prescribed for the volume, and we used a cold-ice viscosity $(\mu)$ of about $1 \times 10^{15} \mathrm{~Pa} \mathrm{~s}^{*}$ (Marshall 2005). Model results, mainly surface velocity measurements, were compared to observed surface velocities to determine model robustness. The model and datasets were used to estimate volume flux across the hillside along the proposed new road, assuming a frozen bed (no basal sliding) and that internal ice deformation is the primary contributor to ice flux down glacier.

* Pascal seconds 


\subsection{Remote sensing}

We used two $2 \mathrm{~m}$ pixel resolution DEMs, provided by the Polar Geospatial Center, which were constructed from WorldView-1 (WV) imagery (0.63 m resolution) collected on 6 February 2011 and WV-3 Imagery (0.34 m resolution) collected on 25 November 2015. We used these DEMs and a LiDAR (light detection and ranging) DEM collected on 12 December 2014 to calculate elevation changes across the $\mathrm{TZ}$ and surrounding region over the course of 5 years. We used established techniques (Nuth and Kääb 2011; Wang and Kääb 2015) to first coregister the three DEMs in the $x-y$ plane and then corrected the imagery in the $\mathrm{z}$ direction. To account for the potential vertical offset associated with the WV DEMs $( \pm 4 \mathrm{~m}),{ }^{*}$ we normalized these DEMs against the higher-spatial-resolution LiDAR DEM (1 m resolution). While much of the topography in this region is changing with time due to snowfall, compaction, and melting, we can use the LiDAR DEM as a baseline if we assume that exposed bedrock maintains a constant elevation between all DEM acquisitions. Through this assumption, we identified a bedrock area of interest (AOI) within the study region (Figure 4, black polygon) and used this AOI to normalize the WV DEMs. We isolated the AOI by masking the surrounding region in each DEM and subtracted the AOI LiDAR DEM from each of the AOI WV DEMs. We then calculated the average offset for each pair (Figures 5 and 6) and applied the offset $(-1.59 \mathrm{~m}$ in $2015,+1.14 \mathrm{~m}$ in 2011) to each WV DEM scene, thereby normalizing each DEM to the higher-spatial-resolution LiDAR DEM. Finally, we differenced the two WV DEMs to determine surface elevation changes over the $\mathrm{TZ}$ and the neighboring hillside during the 58 month timeframe.

We used the DEM acquired in 2015 to determine surface slope and associated aspect of the $\mathrm{TZ}$ and hillside. Slope, aspect, latitude, and terrain shadowing influence solar insolation for each position on the ground, which would influence surface melt and associated elevation loss. If surface elevation loss is tied strictly to in situ surface melt, we expect a positive relationship to exist between surface insolation and changes in elevation.

\footnotetext{
* M. Cloutier, personal communication, 15 August. St. Paul, Minnesota: Polar Geospatial Center.
} 
Figure 4. Digital elevation models (DEMs) from a 2014 LiDAR dataset, a 2011 Worldview (WV) dataset, and a $2015 \mathrm{WV}$ dataset. The entire study area of each DEM is displayed in the first row, with the second row displaying a zoom into the exposed bedrock region (black-outlined polygon) used to normalize these datasets to enable elevation comparisons. The WV images were differenced from the LiDAR image within the black-outlined AOI. The results of the WV-LiDAR differencing are shown in the histograms (Figs. 5 and 6).

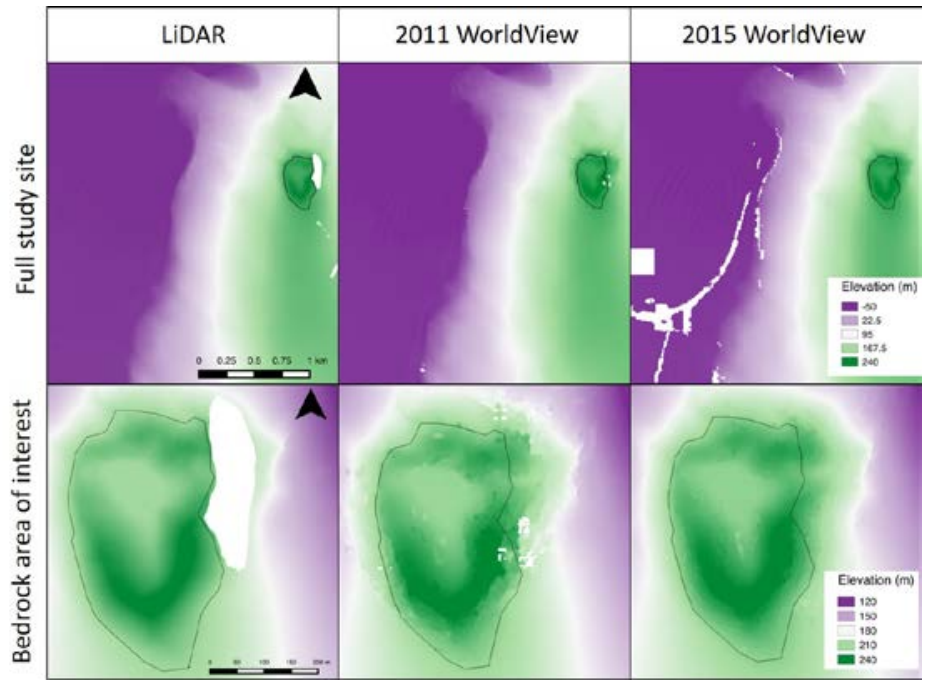

Figure 5. Histogram showing the number of pixels (frequency) on the $y$-axis for each pixel value on the $x$-axis. Pixel value ( $x$-axis) represents the difference between the $2015 \mathrm{WV}$ image and the 2014 LiDAR image over the bedrock $\mathrm{AOI}$ (Fig. 4, black-outlined polygon), which we assume remains constant in elevation. The average difference between the DEMs is $1.59 \mathrm{~m}$ (blue vertical line), and therefore $1.59 \mathrm{~m}$ was subtracted from the entire WV 2015 scene to normalize the image and to enable comparison between the WV DEMs.

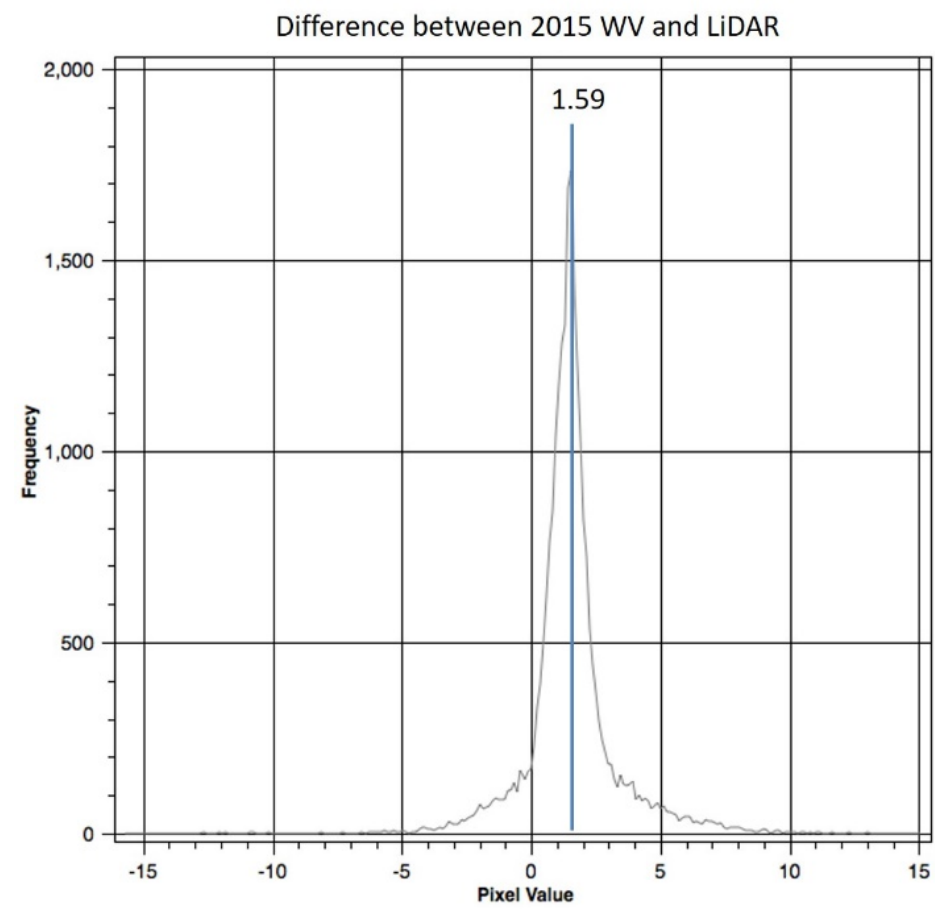


Figure 6. Histogram showing the number of pixels (frequency) on the $y-$ axis for each pixel value on the $x$-axis. Pixel value ( $x$-axis) represents the difference between the 2011 WV image and the 2014 LiDAR image over the bedrock AOI, which we assume remains constant in elevation. The average difference between the DEMs is $1.14 \mathrm{~m}$ (blue vertical line), and therefore $1.14 \mathrm{~m}$ was added to the entire WV 2011 scene to normalize the image and to enable comparison between the WV DEMs.

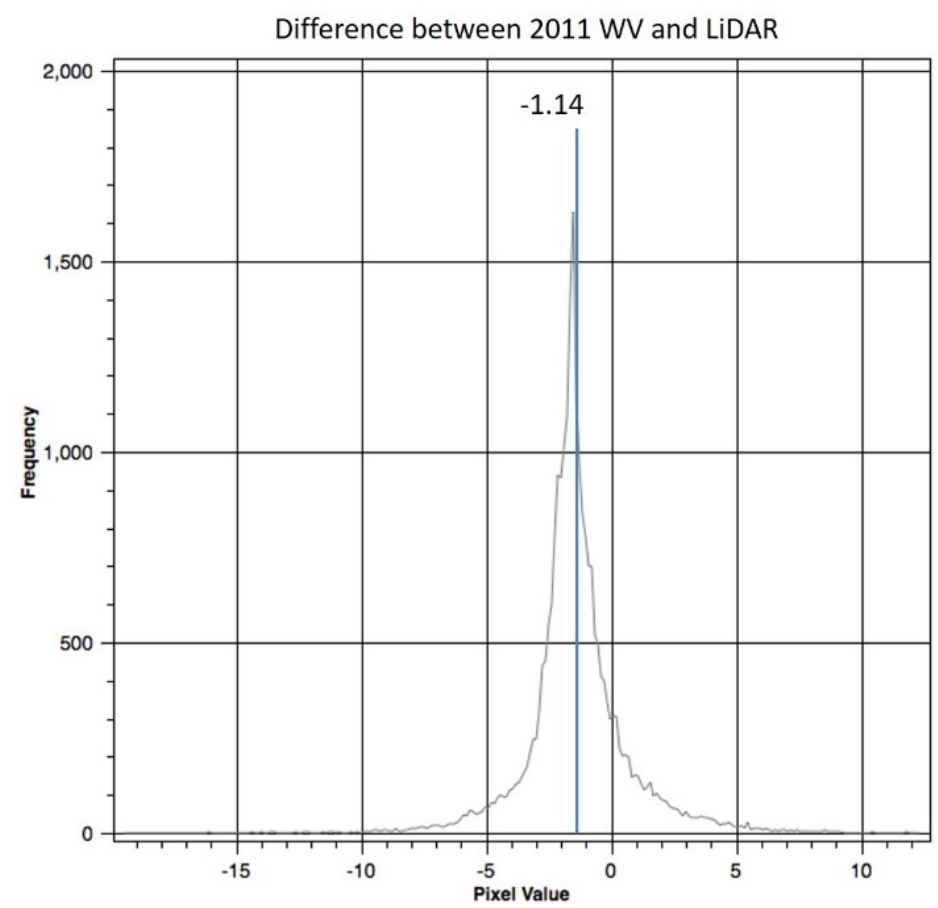

To test this relationship, we used the 2015 DEM to calculate total insolation (reported in watt-hours per square meter) acquired for each pixel in the image between 1 January 2015 and 31 December 2015. The calculation uses a module in ESRI ArcGIS Version 10.3.1 software based on Rich et al. (1994) and $\mathrm{Fu}$ and Rich $(2000,2002)$ to estimate insolation from a hemispherical view shed algorithm. Our input was the November 2015 high-resolution georeferenced DEM, which provides surface slope, aspect, and the view shed required for an insolation $\left(I_{t}\right)$ calculation, which is

$$
I_{t}=D i r_{t}+D i f_{t}+R e f_{t}
$$

where

$D i r_{t}=$ total direct insolation,

$D i f_{t}=$ total diffuse insolation caused by scattering, and

$R E F_{t}=$ reflected insolation caused by surface reflectivity and terrain features. 
Unfortunately, the GIS module does not include an estimate of reflected radiation in the calculation, which at the TZ, could be substantial. The TZ is primarily snow covered during winter months and can have around a 90\% albedo. However, as the summer progresses, bare ice, which has a lower albedo (50\%-70\%, depending on debris or dust cover over the ice) is exposed across the entire hillside, resulting in greater absorption and associated melt. We therefore, consider the combination of direct and diffuse insolation to represent a first-order approximation, considering a likely additional influence from $\operatorname{Ref}_{t}$. 


\section{Results and Discussion}

\subsection{Hillside GPR}

We collected $5.5 \mathrm{~km}$ of $100 \mathrm{MHz}$ and $4.7 \mathrm{~km}$ of $400 \mathrm{MHz}$ GPR data on the TZ hillside. Both antennas successfully imaged bedrock to the maximum thicknesses profiled. Profiles show ice reaching $65 \mathrm{~m}$ in depth with greater thicknesses situated near the top of TZ Hill and towards the east and shallower depths located just up glacier of the bergschrund (i.e., a crevasse separating stagnant ice above from the flowing ice below). Profiles collected just up glacier of the proposed road show ice thicknesses to $50 \mathrm{~m}$ (Figure 7), and profiles at the top of the hillside show a buried symmetrical bedrock feature rises to within $25 \mathrm{~m}$ of the surface with depths reaching 60 $m$ on either side (Figure 8). Significant noise within the radar data exists above the bedrock rise relative to the rest of the profiles collected on the hillside. Elsewhere, conformable stratigraphy is faintly visible to $20-25 \mathrm{~m}$ depth in both the $400 \mathrm{MHz}$ (Figure 8a) and $100 \mathrm{MHz}$ (Figure 8b) data. However, stratigraphy above the symmetrical bedrock rise is nonexistent, and the attenuation is far greater in the region directly above and immediately lateral to this buried peak. Based on the symmetry of the bedrock feature, disrupted stratigraphy above the feature, and surface conformable stratigraphy to either side, we interpret it to be a previously active and now subglacial cinder cone volcano (Figure 8) that geothermally heated and altered the ice above.

Figure 7. A $400 \mathrm{MHz}$ GPR profile showing rough bed topography and ice thicknesses to $50 \mathrm{~m}$. Some stratification is still visible within the top $20 \mathrm{~m}$ of ice.

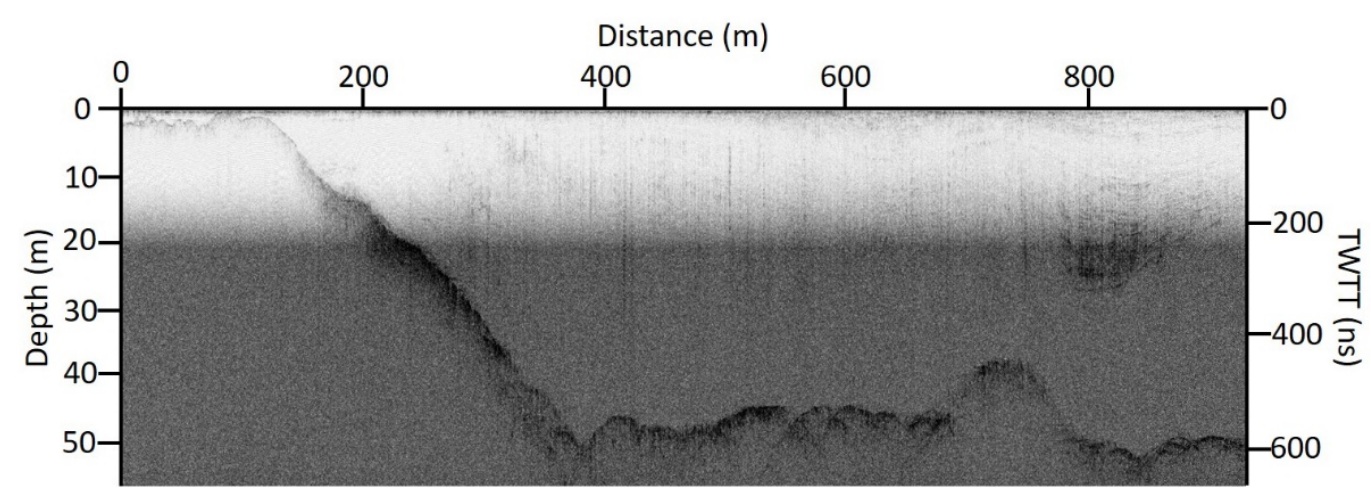


Figure 8. A $400 \mathrm{MHz}$ GPR profile (a) and $100 \mathrm{MHz}$ GPR profile (b) showing bed topography and a likely buried cinder cone (arrow) under the TZ Hillslope. The complex stratigraphy above the cone is similar to noise imaged in temperate glaciers, suggesting that the ice has been thermally altered above the cone. Therefore, we suggest that ice has been situated overtop of the cone since its initial formation or at least since recent thermal activity.

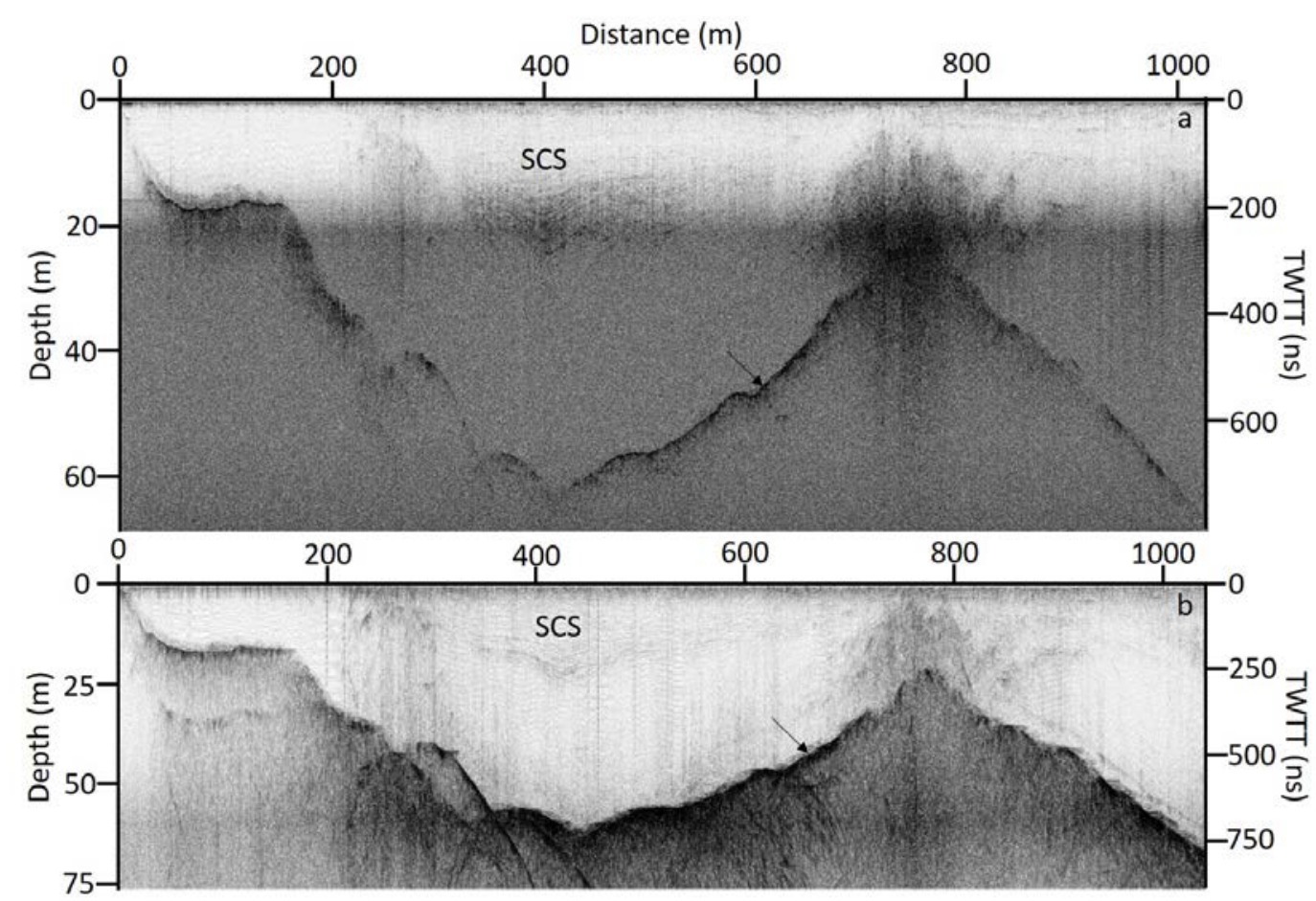

\subsection{Transition Zone GPR}

In January 2015, we collected GPR profiles to understand the subsurface structure of the TZ along the current road (Figure 9). These unpublished profiles, though not collected as part of this project, are presented here because they are useful for understanding the relationship between the hillside and the TZ. These profiles were collected using a GSSI SIR-4000 control unit and model $5103400 \mathrm{MHz}$ antenna. Unlike the GPR data collected in 2016, which included GPS coordinates collected every second, these GPR profiles were distance normalized using handheld Garmin GPS points collected every $20 \mathrm{~m}$, which provides horizontal accuracy of 1-3 $\mathrm{m}$. Three $840 \mathrm{~m}$ long longitudinal profiles were collected along the TZ Road from bedrock near Scott Base to a region where folding was less prominent in the TZ (Figure 2; Figure 9). Five profiles were also collected as oblique cross sections across the TZ Road. Considering this GPR data was not synced with real time GPS data, we use it only to infer subsurface structure of the TZ and not to deduce ice thicknesses as we did in the 2016 survey. Depth calibration was performed using a depth-averaged value of 2.8 for $\dot{\varepsilon}$ 
in equation (1). This value of $\dot{\varepsilon}$ assumes that the TZ consists of snow ( $\dot{\varepsilon}=$ 1.4-2) and firn ( $\dot{\varepsilon}=2-2.4)$ overlying meteoric and marine ice $(\dot{\varepsilon}=3.1-$ $3.2)$.

GPR profiles collected in the TZ (Figure 9) generally revealed structure down to a $15-20 \mathrm{~m}$ depth (150-200 ns TWTT where $\dot{\varepsilon}=2.8)$ where surface conformable stratigraphy exists in the top $3-5 \mathrm{~m}$. Thicker conformable stratigraphy is visible within the syncline of folds crossing the TZ Road and longitudinal GPR profiles; and below the conformable stratigraphy, heavily deformed, discontinuous, and dipping horizons are present. At a 12-15 $\mathrm{m}$ depth, a series of stratified and discontinuous layers are prevalent in each longitudinal profile. The near-surface conformable stratigraphy (o-5 $\mathrm{m}$ depth) is likely recent accumulation and reworked snow cover from yearly road construction operations over heavily deformed and fractured ice (5-10 m depth). The strong GPR horizons at 12-15 $\mathrm{m}$ in depth likely represent discontinuous marine ice frozen onto the bottom of the meteoric ice (as also seen in Campbell et al. 2017). Within the TZ Road GPR profiles, vertical noise bands appear to originate from specific horizons near a $5 \mathrm{~m}$ depth. We interpret these horizons and noise to be caused by laterally continuous water tables within the snow or firn, situated along various horizons. These horizons occur most commonly near the base of the surface-conformable stratigraphy ( $5 \mathrm{~m}$ depth). The occurrence of water at the base of these layers supports our interpretation that the conformable stratigraphy is composed of permeable snow and firn and that the discontinuous layers below are likely impermeable meteoric glacier ice. This geophysical response to water within glacier snow or firn is a wellknown phenomenon (e.g., Campbell et al. 2012).

\subsection{Hillside GPS}

The GPS survey revealed ice-flow velocities ranging from 0.1 to $1.1 \mathrm{~m} \mathrm{a}^{-1}$ with the highest velocities located in the eastern corner of the grid and near the bergschrund above the TZ (Figure 10). Velocities were scaled to meters per year from the 47- to 51-day time-period between stake measurements, assuming velocities remain constant through the year. This assumption is reasonable if the bed is likely frozen due to the average annual temperature near between $-18^{\circ} \mathrm{C}$ and $-20.7^{\circ} \mathrm{C}$ at McMurdo Station (Monaghan et al. 2005). Systematic position uncertainty from the processed baselines was $1.9 \pm 0.01 \mathrm{~cm}$ in the horizontal and $4.7 \pm 1.9 \mathrm{~cm}$ in the vertical. 
Figure 9. A $400 \mathrm{MHz}$ GPR profile collected along the centerline of the TZ Road in January of 2015 showing near surface, conformable stratigraghy (SCS), complex syncline $(S F)$, and anticline folds $(A F)$ of the meteoric ice and discontinuous stratified marine ice below. Also note the vertical noise bands associated with relatively continuous horizons between 3 and $5 \mathrm{~m}$ in depth, which we interpret to be water resting on the firn-ice transition.

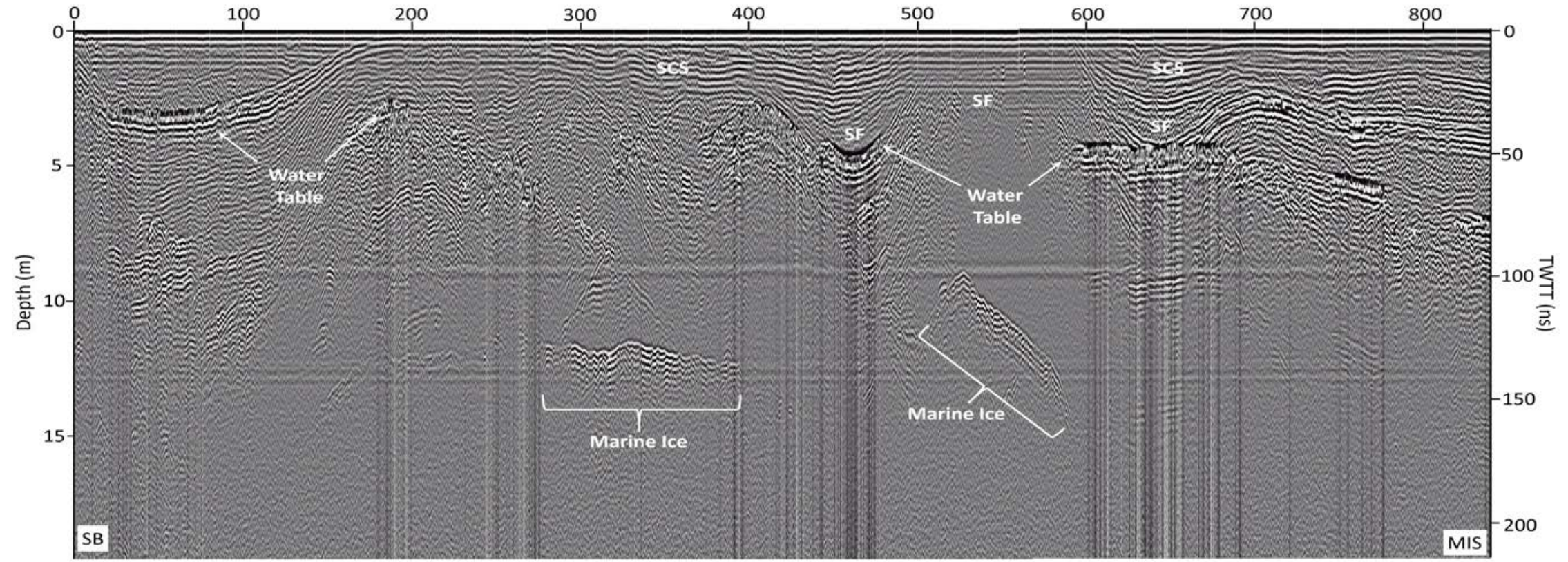


We also assume $1 \mathrm{~cm}$ of bias uncertainty due to the size of the stake hole relative to the distance measured and leveling the survey rod to the same precision at each sample point. Combining systematic and bias uncertainty, our total horizontal positional error is $2.1 \mathrm{~cm}$ at each measurement, which scales to $16.7 \mathrm{~cm} \mathrm{a}^{-1}$ for the duration of a year. Given that ice movement horizontally over 47-51 days ranged between 1 and $15 \mathrm{~cm}$, which corresponds to $0.1-1.1 \mathrm{~m} \mathrm{a}^{-1}$, the uncertainty is small enough to assume that most of the measurements are outside of the error bounds. The velocities result in tensile stresses towards the east and south, which match locations of observed crevassing. The velocity profile along the proposed road range from $0.29 \mathrm{~m} \mathrm{a}^{-1}$ near the exposed bedrock on the western margin of the grid to $0.88 \mathrm{~m} \mathrm{a}^{-1}$ closer to the eastern boundary of the grid.

Figure 10. A map of the 2016 GPR transects with color of the transects indicating measured ice thicknesses on the hillside beside the $T Z$ and arrows indicating ice-flow velocities measured by GPS stakes (green circles) during November 2016-January 2017. The background natural-color WV image shows that most of the hillside is composed of blue ice, with snow accumulation occurring between the compression folds and the hill. The buried cinder cone $(B C C)$ and one potential line for the proposed road $(P R)$ discussed in the text are also noted in this figure.

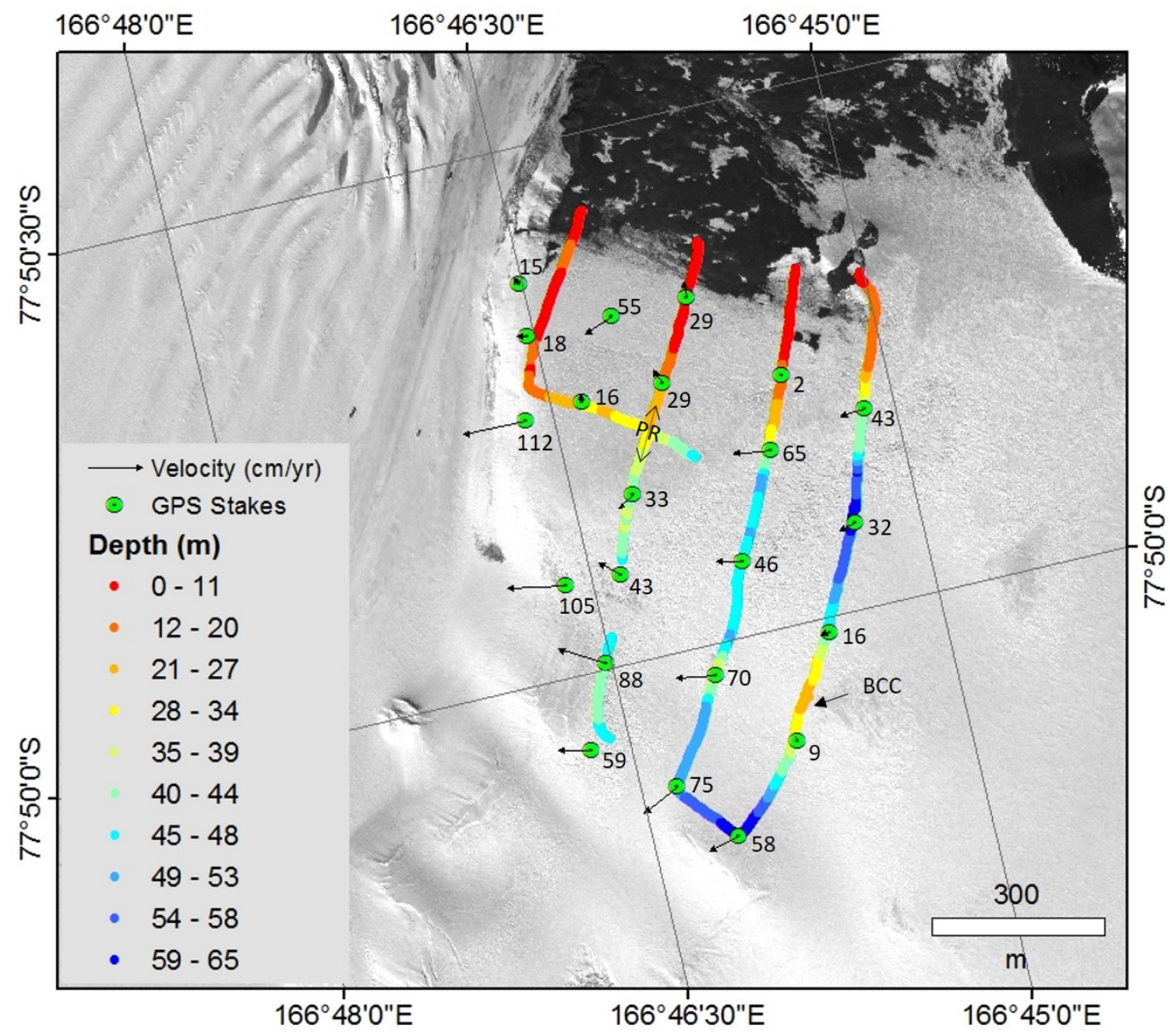




\subsection{Numerical modeling}

Snapshot three-dimensional numerical model results show ice-flow velocities between 0.1 and $1.2 \mathrm{~m} \mathrm{a}^{-1}$ across the hillside, which increase to the southeast (Figure 11). The average modeled ice velocity across the proposed road location is $0.25 \mathrm{~m} \mathrm{a}^{-1}$, slightly slower than the observed range of the surface velocities. This result is reasonable considering velocities likely tend towards $0 \mathrm{~m} \mathrm{a}^{-1}$ near and at the frozen bed. Velocities are slowest near the western glacier margin where ice thicknesses approach o $\mathrm{m}$ in depth and over the buried cinder cone near the top of the TZ hillside where velocities are on the order of $0.1 \mathrm{~m} \mathrm{a}^{-1}$. These modeled results align with field-measured velocities from GPS surveys. If a road is installed across this region, the two possible options include blasting ice to place the road on solid ground or creating an ice road. Either option has inherent challenges associated with maintenance. In the case of an on-ice road, as is currently used to access the runway, the measured and modeled ice-flow velocities (averaging $0.25 \mathrm{~m} \mathrm{a}^{-1}$ but reaching close to $1 \mathrm{~m} \mathrm{a}^{-1}$ ) would require significant yearly maintenance. Another note worth mentioning here is that the entire hillside was predominantly ice with minimal snow and firn cover. Hence, minimal snow or firn would be readily available from the study area for quarrying to improve ice road conditions during maintenance.

To estimate how much ice would need to be removed to create a bedrockbased road, we integrated ice volume crossing a slice in our three-dimensional numerical model. The slice was determined using coordinates from the GPS stakes we installed in 2016 along what we deemed to be the most likely road transect based on trying to minimizing surface slope and ice thickness. Numerical simulations of ice flow, which closely match observed GPS-measured surface velocities, suggest that over $204 \mathrm{~m}^{3}$ $(187,000 \mathrm{~kg})$ of ice crosses this single slice each year (Figure 11). While this initial calculation of ice removal does not account for the volume of ice outside of our gridded study region and other road transects could be proposed, the calculation shows that significant construction activities would be required yearly to maintain a bedrock-based road. These results suggest that a bedrock-based road would be even more problematic than an ice road, if not impossible, due to the significant volume of yearly ice removal. 
Figure 11. Snapshot of the three-dimensional finite element numerical model of the TZ hillside showing modeled ice flow velocities $\left(\mathrm{m} \mathrm{a}^{-1}\right)$ and a slice of the proposed road. Model dimensions are based on interpolated ice thicknesses determined from GPR and a surface DEM provided by Polar Geospatial Services. Model velocities match observed velocities quite well with the most obvious example being represented by low velocities over the buried cinder cone ( $B C C$ ) region, also noted in Figs. 6 and 7 . The proposed road slice was used to integrate yearly volume of ice crossing the region.

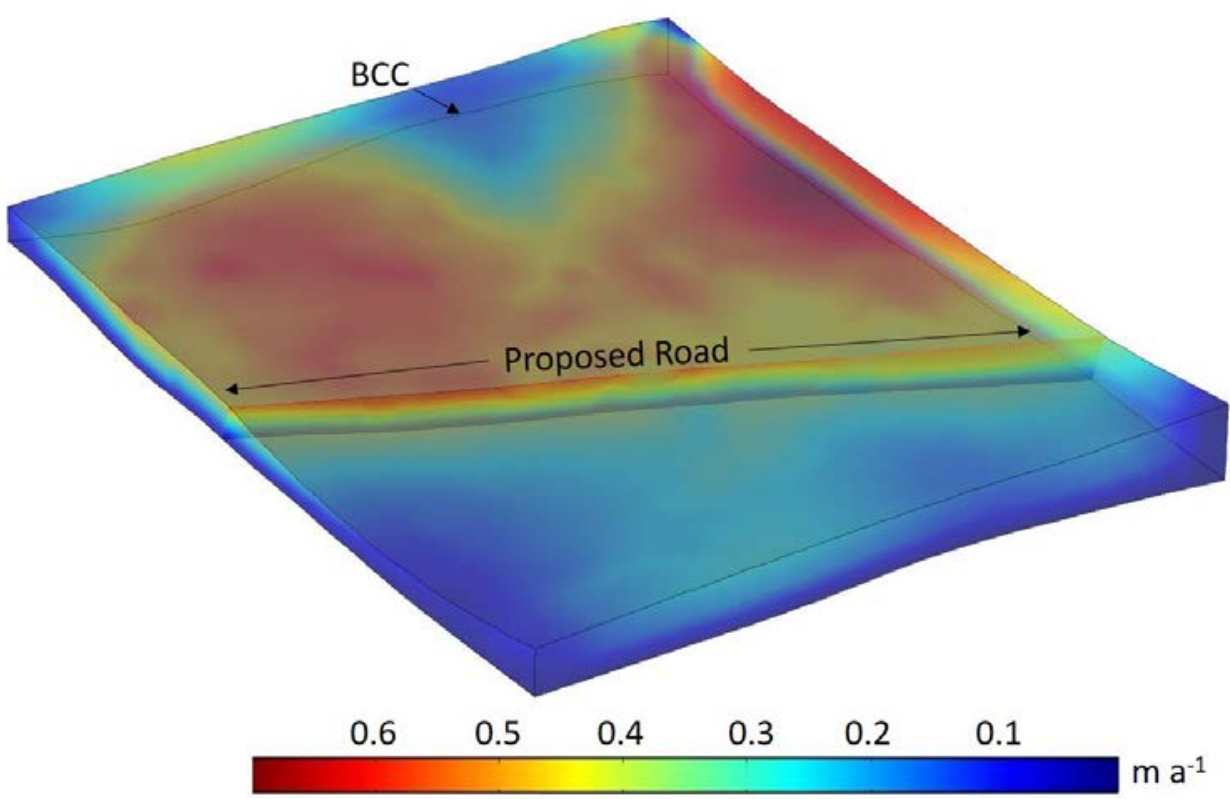

\subsection{Remote sensing}

Results show the hillside lost between 1 and $3.3 \mathrm{~m}$ in elevation from 2011 to 2015 (Figure 12). The DEM difference does not account for tidal phase difference over the ice-shelf region, but the maximum impact of tide phase on ice elevation is $80 \mathrm{~cm}$ in this region (Padman and Fricker 2005). The clear east-west trending linear features within the $\mathrm{TZ}$ correspond with compression folds caused by MIS buttressing against Hut Point. The elevation changes within this fold region result from the movement of the compression folds and redistribution of drifting snow between each fold during the 5-year time frame. Slope increases from the top of the hill towards the TZ Road and ranges from $5^{\circ}$ to $20^{\circ}$ with steeper sections at the TZ-hillside bergschrund (Figure 13). Results, as expected, show low surface slopes across the TZ $\left(0^{\circ}-4^{\circ}\right)$ except for on the slopes of each compression fold. An estimate of solar insolation across the TZ and neighboring hillside based on the 2015 DEM shows that the hillside is oriented mostly westward whereas the TZ exhibits a range of orientations depending on the orientation of the folds and associated anticlines or synclines. The so- 
lar insolation calculation for 2015 shows that the hillside absorbs more solar insolation over the course of a year relative to the TZ (Figure 14). This corresponds well with the elevation loss being greater on the hillside than within the TZ (Figure 12).

Figure 12. The elevation changes between the normalized WV 2011 and normalized WV 2015 DEM scenes. A majority of the region experienced a decrease in elevation, up to $\sim 3.3 \mathrm{~m}$, between 2011 and 2015.

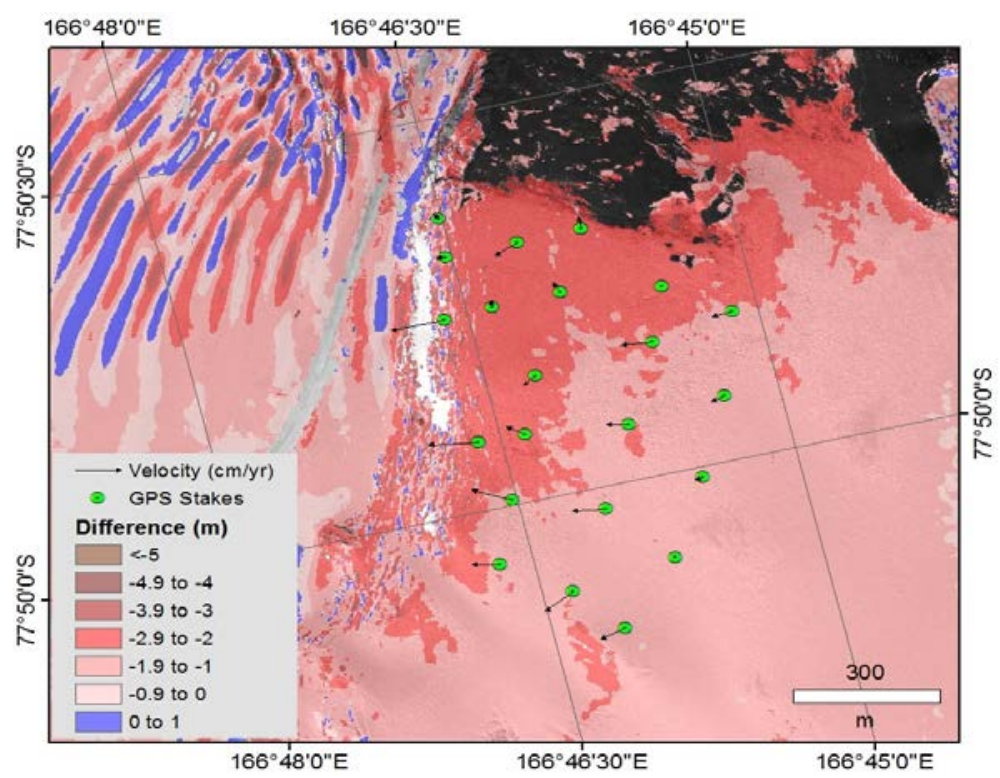

Figure 13. A map of surface slope derived from the WV 2015 DEM. Surface slopes on the hillside range from $5^{\circ}$ to $28^{\circ}$ with increasing slopes near the bergschrund, which is located immediately above the TZ road. Slopes on the ice shelf are small $\left(1^{\circ}-4^{\circ}\right)$.

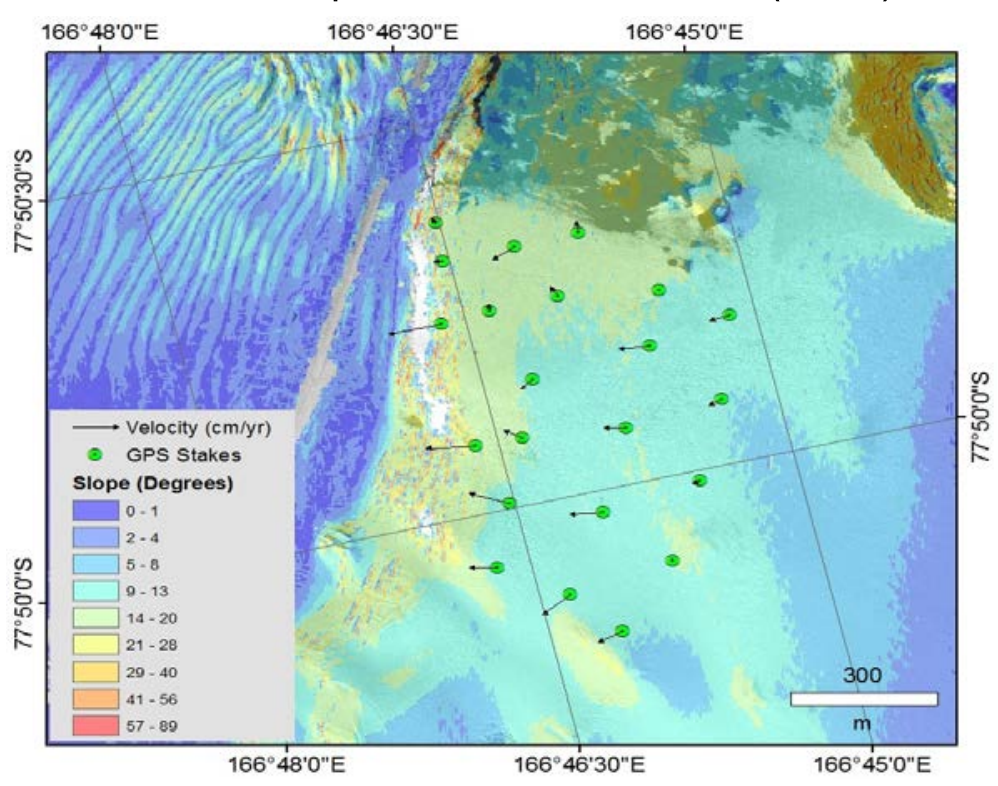


Figure 14. Modeled solar insolation, which includes only direct and total diffuse insolation calculated for 2015 based on the 2015 WV

DEM. Note the lower values in the TZ relative to the TZ hillslope.

Reflected insolation is not included within this model.

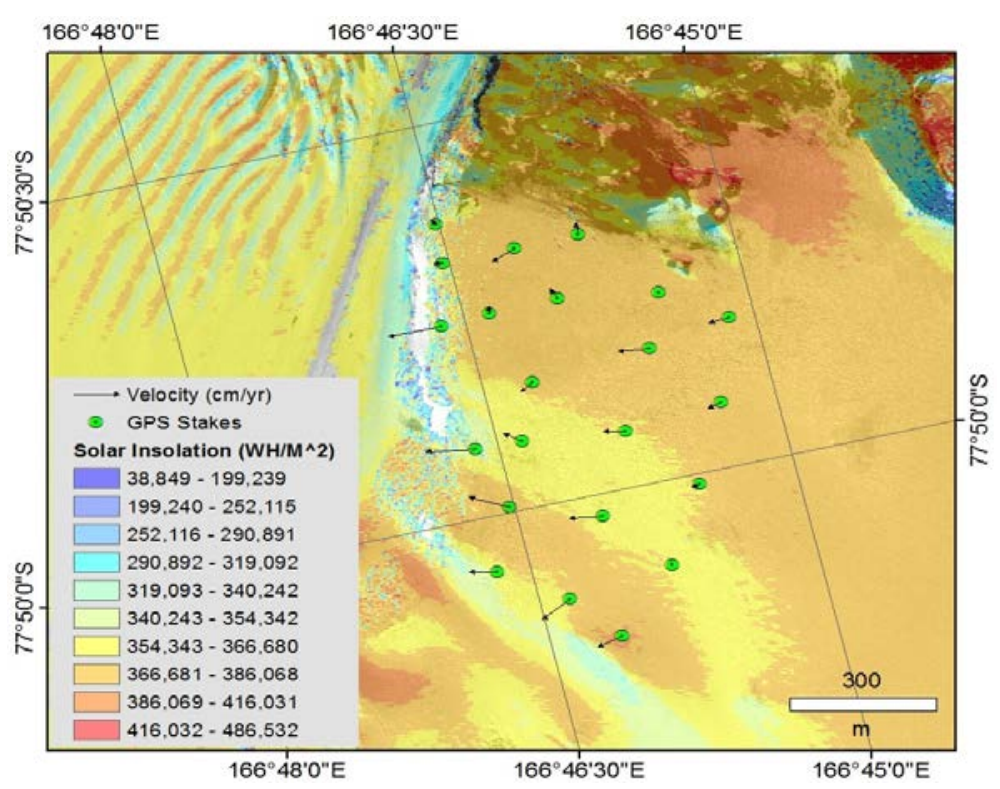

The dominant forces that influence most glacier elevation change include surface or basal melting, thinning from tensile stresses, and calving. Several variables potentially contribute to the surface elevation changes that the MIS TZ and associated hillside have undergone between 2011 and 2015. The similarity between estimated decreased elevation and solar insolation on the hillside (Figures 12 and 14) suggests that surface melt is likely the dominant factor in mass loss at this study area. Water runoff from the hillside is also regularly observed during the summer months (Shoop et al. 2014). The TZ requires more examination to determine the extent of change and leading contributors as this study has not accounted for the location of compression folds, the tidal signature, or mass redistribution from snow deposition. However, based on results from this study, it is likely that much of the meltwater in the TZ snow and firn pack originates from the hillside. This is because the hillside is primarily impermeable ice, suggesting that any surface melt flows onto the TZ.

Negative impacts of this meltwater on the TZ road and surrounding region, although currently unknown, are likely (Kingslake et al. 2017). While our site is relatively small scale, local observations typically have some correspondence with regional observations, albeit local controls (such as bedrock and local meteorology) can also impact the dynamics at a local scale (Campbell et al. 2013). Our results also suggest that the recent terminus 
TZ fracture occurring in 2016 (Figure 3) corresponds with other terminus and MIS events, including the breakoff of the $14 \mathrm{~km}^{2}$ iceberg discussed by Banwell et al. (2017). Their results suggest that ocean sea swell probably contributed to these terminus events and associated upstream MIS dynamic responses. It is likely that a lack of buttressing sea ice and open water in front of McMurdo ice Shelf during the most recent summer seasons have exacerbated this effect, and some studies suggest that such influences will increase in the future (Robinson et al. 2010). However, numerous studies also cite the influence of meltwater on ice-shelf stability (e.g., Banwell 2017; Kingslake et al. 2017).

Meltwater adds a significant load, causes hydrofracturing, and can result in full thickness weaknesses within an ice shelf (Banwell 2017). With recent studies suggesting that surface meltwater appears to be increasing across Antarctica, the meltwater reaching MIS and the TZ may become a more important logistical concern to the USAP and New Zealand Antarctic Program in future years. 


\section{Conclusions and Recommendations}

The TZ hillside has ice thicknesses reaching upwards of $65 \mathrm{~m}$ and ice flow velocities ranging between 0.1 and $1.1 \mathrm{~m} \mathrm{a}^{-1}$. The hillside is an ablation zone that has lost up to $3.3 \mathrm{~m}$ of elevation due to surface melt between 2011 and 2015. The substantial quantity of ice on the hillside, steep slopes, minimal snow and firn cover, and ice velocities suggest that it would be challenging, at best, to construct and maintain a new access road from Scott Base to MIS in this area to replace the current TZ access road. Lastly, the hillside lacks snow or firn cover, resulting in meltwater being transported and deposited into the TZ during summer months. The impact of this meltwater on the TZ and the overall stability of the TZ is still relatively unknown. Recommendations for future work include a more detailed assessment of available remote-sensing data over the TZ and the broader Hut Point Peninsula to determine (1) its overall stability; (2) the subsurface structure at the TZ in greater detail to understand the extent, pathways, and seasonal influence of meltwater on the TZ; and (3) whether another appropriate location exists to access MIS from Hut Point Peninsula. Ultimately, the TZ and nearby hillside do not appear to be suitable access points to MIS for the long term, so we believe these three recommended studies are important, particularly if higher temperatures continue to occur during summer months. 


\section{References}

Banwell, A. F. 2017. Ice Shelf Stability Questioned. Nature 544:306-307.

Banwell, A. F., I. C. Willis, G. J. MacDonald, B. Goodsell, D. P. Mayer, A. Powell, and D. MacAyeal. 2017. Calving and Rifting on the McMurdo Ice Shelf, Antarctica. Annals of Glaciology. doi:10.1017/aog.2017.12.

Campbell, S., K. Kreutz, C. Wake, E. Osterberg, S. Arcone, D. Introne, D. Winski, and K. Volkening. 2012. Melt Regimes, Internal Stratigraphy, Flow Dynamics, and Glaciochemistry of Three Glaciers in the Alaska Range. Journal of Glaciology 58 (207): 99-109.

Campbell, S., G. Balco, H. Conway, C. Todd, K. Huybers, C. Simmons, and M. Vermeulen. 2013. Radar-Detected Englacial Stratigraphy in the Pensacola Mountains, Antarctica: Implications for Recent Changes in Ice Flow and Accumulation. Annals of Glaciology 54 (63): 91-100.

Campbell, S., Z. Courville, S. Sinclair, and J. Wilner. 2017. Brine, Englacial Structure, and Basal Properties Near the Terminus of McMurdo Ice Shelf, Antarctica. Annals of Glaciology 58 (74): 1-11. doi:10.1017/aog.2017.26.

Fu, P., and P. M. Rich. 2000. The Solar Analyst 1.o Manual. Lawrence, KS: University of Kansas, Helios Environmental Modeling Institute (HEMI).

- 2002. A Geometric Solar Radiation Model with Applications in Agriculture and Forestry. Computers and Electronics in Agriculture 37:25-35.

Jansen, D., A. J. Luckman, A. Cook, S. Bevan, B. Kulessa, B. Hubbard, and P. R. Holland. 2015. Brief Communication: Newly Developing Rift in Larsen C Ice Shelf Presents Significant Risk to Stability. The Cryosphere 9:1223-1227. doi:10.5194/tc-91223-2015.

Joughin, I., B. E. Smith, and B. Medley. 2014. Antarctica Marine Ice Sheet Collapse Potentially Under Way for the Thwaites Glacier Basin, West. Science 344 (6185): 735-738. doi:10.1126/science.1249055.

Kingslake, J., J. C. Ely, I. Das, and R. E. Bell. 2017. Widespread Movement of Meltwater onto and across Antarctic Ice Shelves. Nature 544:349-364.

Marshall, S. J. 2005. Recent Advances in Understanding Ice Sheet Dynamics. Earth and Planetary Science Letters 240 (2): 191-204. doi:10.1016/j.epsl.2005.08.016.

Monaghan, A. J., D. H. Bromwich, J. G. Powers, and K. W. Manning. 2005. The Climate of the McMurdo, Antarctica, Region as Represented by One Year of Forecasts from the Antarctic Mesoscale Prediction System. Journal of Climate 18:11741189.

Nuth, C., and A. Kääb. 2011. Co-Registration and Bias Corrections of Satellite Elevation Data Sets for Quantifying Glacier Thickness Change. Cryosphere 5:271-290. 
Padman, L., and H. A. Fricker. 2005. Tides on the Ross Ice Shelf Observed with ICESat. Geophysical Research Letters 32:L14503.

Paige, R. A. 1968. Sub-Surface Melt Pools in the McMurdo Ice Shelf, Antarctica. Journal of Glaciology 7 (51): 511-516.

Rich, P. M., R. Dubayah, W. A. Hetrick, and S. C. Saving. 1994. Using Viewshed Models to Calculate Intercepted Solar Radiation: Applications in Ecology. American Society for Photogrammetry and Remote Sensing Technical Papers, 524-529.

Rignot, E., J. Mouginot, M. Morlighem, H. Seroussi, and B. Scheuchl. 2014. Widespread, Rapid Grounding Line Retreat of Pine Island, Thwaites, Smith, and Kohler Glaciers, West Antarctica, from 1992 to 2011. Geophysical Research Letters 41:3502-3509. doi:10.1002/2014GLo60140.

Robinson, N. J., M. J. M. Williams, P. J. Barrett, and A. R. Pyne. 2010. Observations of Flow and Ice-Ocean Interaction beneath the McMurdo Ice Shelf, Antarctica. Journal of Geophysical Research 115:C03025. doi:10.1029/2008JCo05255.

Shoop, S., J. Hills, and J. Uberauga. 2014. Maintenance and Drainage Guidance for the Scott Base Transition, Antarctica. ERDC-CRREL TR-14-25. Hanover, NH: U.S. Army Engineer Research and Development Center.

Wang, D., and A. Kääb. 2015. Modeling Glacier Elevation Change from DEM Time Series. Remote Sensing 7:10117-10142. doi:10.3390/rs70810117. 


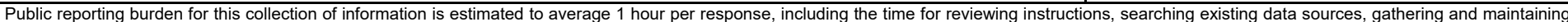

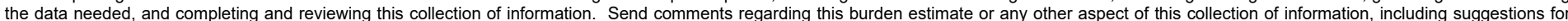

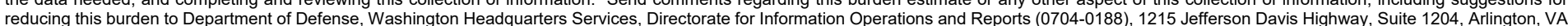

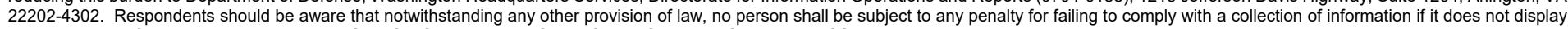
a currently valid OMB control number. PLEASE DO NOT RETURN YOUR FORM TO THE ABOVE ADDRESS.
1. REPORT DATE (DD-MM-YYYY)
2. REPORT TYPE
April 2018
Technical Report/Final

\section{TITLE AND SUBTITLE}

Structure and Stability of the McMurdo Ice Shelf Transition Zone and Glaciated Hillside near Scott Base, Antarctica

3. DATES COVERED (From - To)

5a. CONTRACT NUMBER

5b. GRANT NUMBER

5c. PROGRAM ELEMENT NUMBER

\section{AUTHOR(S)}

\section{5d. PROJECT NUMBER}

Seth Campbell, Nathan Lamie, and Kristin Schild

5e. TASK NUMBER

EP-ANT-16-32

5f. WORK UNIT NUMBER

\section{PERFORMING ORGANIZATION NAME(S) AND ADDRESS(ES)}

U.S. Army Engineer Research and Development Center (ERDC)

Cold Regions Research and Engineering Laboratory (CRREL)

8. PERFORMING ORGANIZATION REPORT NUMBER

72 Lyme Road

Hanover, NH 03755-1290

ERDC/CRREL TR-18-6

9. SPONSORING / MONITORING AGENCY NAME(S) AND ADDRESS(ES)

National Science Foundation, Office of Polar Programs

2415 Eisenhower Avenue

Alexandria, VA 22314

10. SPONSOR/MONITOR'S ACRONYM(S)

NSF

11. SPONSOR/MONITOR'S REPORT NUMBER(S)

\section{DISTRIBUTION / AVAILABILITY STATEMENT}

Approved for public release; distribution is unlimited.

\section{SUPPLEMENTARY NOTES}

Engineering for Polar Operations, Logistics, and Research (EPOLAR)

\section{ABSTRACT}

We used ground-penetrating radar and Global Positioning System surveys in November 2015 and January 2016 to determine ice depth and ice flow velocities of a glacier-covered hillside neighboring the Transition Zone (TZ) on McMurdo Ice Shelf (MIS), Antarctica. We also analyzed two available high-resolution digital elevation maps to establish how surface elevations are changing across the region. These surveys were conducted to determine if the TZ Road, the primary U.S. Antarctic Program access to ice-shelf operations, can be relocated onto the hillside if it becomes unpassable in the future. The results suggest that construction and maintenance of a road on the TZ hillside would be challenging due to (1) steep slopes, (2) minimal snow and firn cover available for maintenance activities, (3) significant annual changes to the surface, and (4) substantial ice thicknesses and ice flow velocities that will alter any constructed road on an annual basis. Despite these primary findings, the observed change in ice cover both on the hillside and within the transition zone itself suggest that efforts to develop a new road should continue to help ensure long-term access and use of ice-shelf-based facilities for McMurdo and Scott Stations.

\section{SUBJECT TERMS}

Digital elevation models, EPOLAR, Glaciers, Ground penetrating radar, Ice sheets, McMurdo Station (Antarctica), NSF, Roads--Design and construction--Cold weather conditions

\section{SECURITY CLASSIFICATION OF:}

\section{a. REPORT}

Unclassified

\section{b. ABSTRACT}

Unclassified

\section{c. THIS PAGE}

Unclassified

\begin{tabular}{c|c}
$\begin{array}{c}\text { 17. LIMITATION } \\
\text { OF ABSTRACT }\end{array}$ & $\begin{array}{c}\text { 18. NUMBER } \\
\text { OF PAGES }\end{array}$ \\
SAR & 33
\end{tabular}

19a. NAME OF RESPONSIBLE PERSON

19b. TELEPHONE NUMBER (include area code) 